\title{
PENERAPAN TEKNOLOGI BIOFERMENTASI UNTUK PEMBUATAN PAKAN TERNAK PADA KELOMPOK TANI TERNAK TULUS NADI DI DESA BUAHAN
}

\author{
D.N.K.P Negara ${ }^{1}$, T.G.T. Nindhia ${ }^{1}$, I.P. Ariastawa ${ }^{2}$
}

\begin{abstract}
ABSTRAK
Pertanian dan peternakan merupakan mata pencaharian utama sebagaian besar masyarakat Desa Buahan, Kec. Payangan-Gianyar. Untuk dapat lebih mengoptimalkan potensi peternakan, di desa ini banyak terbentuk kelompok tani ternak salah satunya adalah Kelompok Tani Ternak Tulus Nadi di Banjar Gambih. Dalam perjalannnya, kegiatan peternakan yang dilakukan masih bersifat konvensional dengan mengandalkan ketersediaan pakan ternak yang masih sangat tergantung pada ketersediaan lahan. Padahal dengan sentuhan teknonogi biofermentasi limbah organik seperti jerami dapak dimanfaatkan untuk menghasilkan pakan ternak yang berkualitas. Untuk alasan tersebut telah dilakukan sosialisasi dan praktek langsung pemanfaatan limbah jerami sebagai pakan ternak dengan teknologi biofermentasi dengan melibatkan narasumber yang berkompeten di bidangnya, anggota Kelompok Tani Ternak Tulus Nadi dan masyarakat sekitar peternakan serta mahasiswa peserta KKN PPM XIX Desa Buahan. Dari kegiatan yang dilakukan dapat disimpulkan bahwa; peternak sangat antusias mengikuti pelatihan, peternak mengetahui dan dapat membuat pakan ternak berkualitas dari limbah jerami dengan teknologi biofermentasi dan dapat pula memanfaatkan kotoran ternak menjadi pupuk yang lebih berkualitas dengan sentuhan biofermentasi. Pada akhirnya kegiatan ini diharapkan dapat meningkatkan produksi ternak dan produksi pupuk organic dengan sentuhan teknologi biofermentasi.
\end{abstract}

Kata kunci : biofermentasi, limbah jerami, pakan ternak, kelompok tani

\begin{abstract}
Agriculture and animal husbandry are the main livelihoods of the majority of the people of Buahan Village, Payangan District-Gianyar Regency. To be able to further optimize the potential of livestock, in this village many livestock farmer groups were formed, one of which was the Tulus Nadi Livestock Farmers Group in Banjar Gambih. In its journey, animal husbandry activities carried out are still conventional by relying on the availability of animal feed which is still very dependent on the availability of land. Even though with a touch of bio-fermentation technology, organic waste such as straw is used to produce quality animal feed. For this reason, the socialization and direct practice of using straw waste as animals feed with bio-fermentation technology have been undertaken. This activity involves competent speakers in the field, members of the Tulus Nadi Livestock Farmers Group and the communities around the farm as well as students participating in KKN PPM XIX Buahan Village. From the activities carried out, it can be concluded that; breeders are very enthusiastic about training, breeders know and can make a quality animal feed from straw waste with biofermentation technology and can also utilize livestock manure into higher quality fertilizers with a touch of bio-fermentation. In the end, this activity is expected to increase livestock and organic fertilizer productions with a touch of bio-fermentation technology.
\end{abstract}

Keywords: bio-fermentation, straw waste, animal feed, livestock farmers group

\footnotetext{
${ }^{1}$ Teknik Meisn Fakultas Teknik Universitas Udayana, devputranegara@gmail.com

${ }^{1}$ Teknik Meisn Fakultas Teknik Universitas Udayana, nindhia@yahoo.com

${ }^{2}$ Program Studi Ilmu Peternakan Universitas Udayana, ariastawa@yahoo.com
} 


\section{PENDAHULUAN}

Provinsi Bali dikenal sebagai destinasi wisata dunia dan menjadi tujuan wisata utama di Indonesia. Segala usaha dilakukan untuk terus meiningkatkan pembangunan di sektor wisata ini. Di sisi lain terpusatnya investasi sektor wisata di pusat-pusat wisata terutama yang di daerah perkotaan menyebabkan terjadi ketimpangan dengan pembangunan di sektor pertanian dan peternakan yang merupakan mata pencaharian sebagaian besar masyarakat Bali terutama di pedesaan. Sebagai akibatnya adalah kontribusi dari sector pariwisata dan sector pertanian dan peternakan terhadap PDRB Bali selama lima tahun (2010 sampai 2014) mengalami ketimpangan. Dari kurun waktu 2010 sampai tahun 2014, kontribusi sektor pariwisata meningkat tajam dari 23,47\% menjadi 29,89\%, sementara kontribusi sektor pertanian-peternakan pada periode yang sama justru mengalami penurunan dari 26,18\% pada menjadi 19,17\% [1]. Untuk mengatasi hal ini, belakanagn sektor pertanian dan peternakan mulai digenjot melalui pengembangan sistem pertanian terintegrasi (simantri) [2] dan kelompok-kelompok tani ternak, salah satunya adalah Kelompok Tani Ternak Tulus Nadi yang berlokasi di Banjar Gambih Desa Buahan Payangan.

Dalam mengelola peternakan ini diperlukan pakan yang sangat tergantung pada ketersediaan lahan. Seperti diketahui Pulau Bali merupakan pulau kecil dengan ketersediaan lahan hijau yang terbatas dan peternak pun memiliki lahan yang terbatas pula. Keadaan ini berakibat terbatasnya pula ketersediaan pakan ternak [3]. Salah satu jalan keluar masalah ini adalah memanfaatkan limbah pertanian dengan memberikan sutu sentuhan teknologi. Salah satu limbah pertanian yang selama ini belum termanfaatkan adalah jerami. Untuk mempercepat proses limbah jerami biasanya dibakar. Di Desa Buahan potensi jerami padi cukup besar terutama diperoleh pasca panen. Namun belum dikelola secara optimal menjadi sumber pakan ternak yang cukup menjanjikan untuk mengantisipasi permasalahan sumber pakan hijauan yang semakin sulit didapatkan karena lahan yang tersedia semakin sempit dan petani kecenderungan menanam tanaman perkebunan atau dibandingkan menanam hijauan pakan ternak [4]. Dengan alasan tersebut diperlukan sentuhan teknologi untuk mengolah jerami ini menjadi pakan ternak yang berkualitas yaitu melalui teknologi biofermentasi biochast. Melalui teknologi ini anggota Kelompok Tani dan Ternak Tulus Nadi diberikan sosialisasi dan bimbingan teknis pengelolaan jerami padi menjadi pakan ternak. Tujuan kegiatan ini adalah untuk meningkatkan pengetahuan dan keterampilan anggota kelompok ternak tentang pembuatan pakan ternak dari jerami padi sebagai sumber pakan dengan teknologi biofermentasi.

\section{METODE PELAKSANAAN}

\subsection{Sasaran Kegiatan}

Yang menjadi sasaran kegiatan ini adalah Kelompok Tani dan ternak Tulus Nadi yang berlokasi di Banjar Gambih Desa Buahan Kecamatan Payangan-Gianyar dan masyarakat di sekitar lokasi kelompok tani ini. Kelompok tani dan ternak ini beranggotakan 26 orang dan diketuai oleh Bapak Made Warsa.

\subsection{Metode Kegiatan}

Kegiatan ini dilaksanakan melalui 2 metode yaitu metode penyuluhan dan demonstrasi dengan nara sumber Bapak I Putu Ariastawa. Sebelum pembuatan pakan ternak kelompok tani diberikan penyuluhan tentang teknologi biofermentasi, keuntungan serta cara pembuatannya dengan cara yang mudah dimengerti. Setelah teorinya dimengerti 
selanjutnya dilakukan demonstrasi pengolahan jerami padi dengan teknologi biofermentasi biochast. Selanjutnya anggota kelompok tani yang melaksanakan dan mengerjakan sesuai yang didemonstrasikan oleh nara sumber.

\section{PELKSANAAN DAN HASIL}

Kegiatan ini dilaksanakan pada tanggal ini dilaksanakan pada hari Sabtu, 10 Agustus 2019 bertempat di Kelompok Tani Ternak Tulus Nadi dan peserta KKN PPM periode XIX Unud di Desa Buahan. Langakah-langkah pembuatan pakan ternak dari jerami dengan biofermentasi biochast:

1. Disiapkan air bersih sebanyak 10 liter

2. Siapkan larutan gula merah sebanyak $10 \%$ dari jumlah air $(1 \mathrm{~kg})$ dan masukkan ke dalam air 10 liter.

3. Siapkan Biochast $1 \%$ dari jumlah air $(100 \mathrm{cc})$

4. Siapkan Urea $0,5 \%$ dari jumlah air (50 gram)

5. Biochast dan urea dimasukkan ke dalam air dan diadu sehingga bahan-bahan tersebut larut secara merata. Diamkan larutan selama 30-60 menit

6. Jerami padi dipotong-potong dengan panjang sekitar 20-40 cm lalu dicelupkan ke dalam larutan tadi selama 1-2 menit sampai seluruh jerami padi terbasahi oleh larutan

7. Jerami padi diangin-anginkan sekitar $2-3$ jam, selanjutnya dapat diberikan pada ternak

8. Untuk pemanfaatan jerami padi sebagai sumber pakan ternak untuk jangka waktu yang lama (disimpan), maka jerami yang telah terolah dibungkus plastik atau bungkus lain yang tidak tembus udara, lalu ujung-ujungnya diikat agar tidak kemasukan oksigen.

9. Didiamkan selama 1-2 minggu. Jerami padi yang sudah diolah dapat disimpan selama 3-4 bulan.

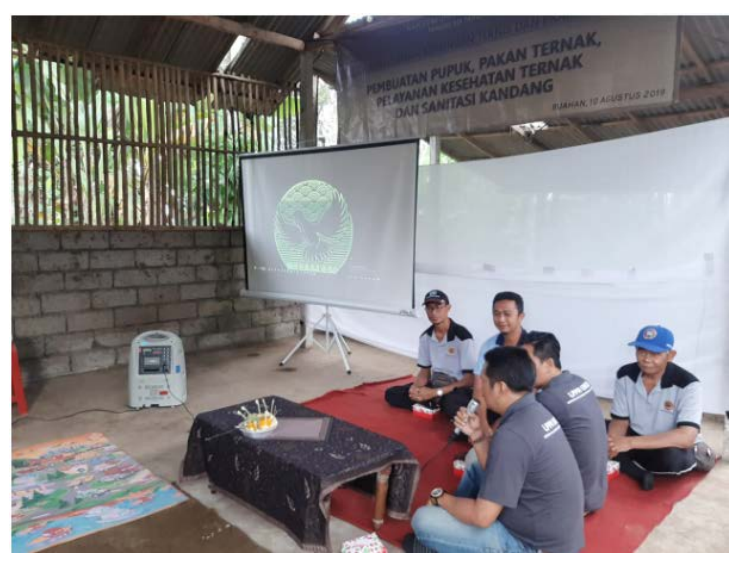

Gambar 1. Penyuluhan biofermentasi biochast

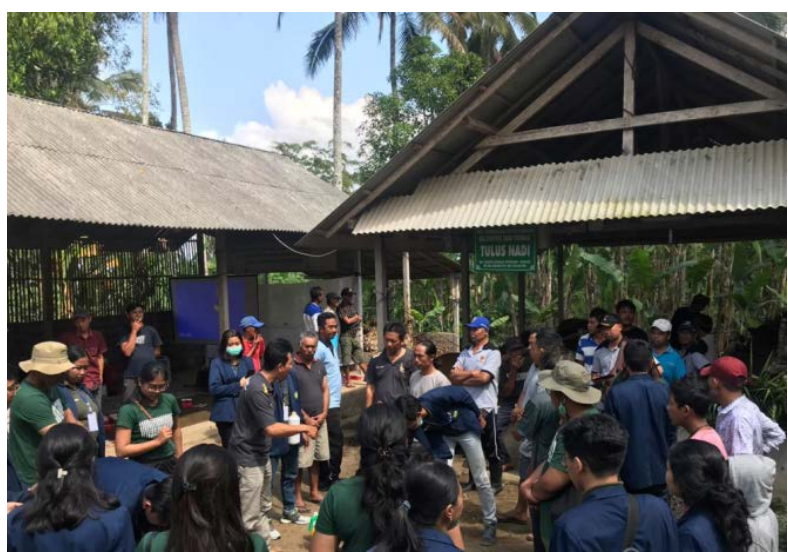

Gambar 2. Demonstrasi biofermentasi biochast 

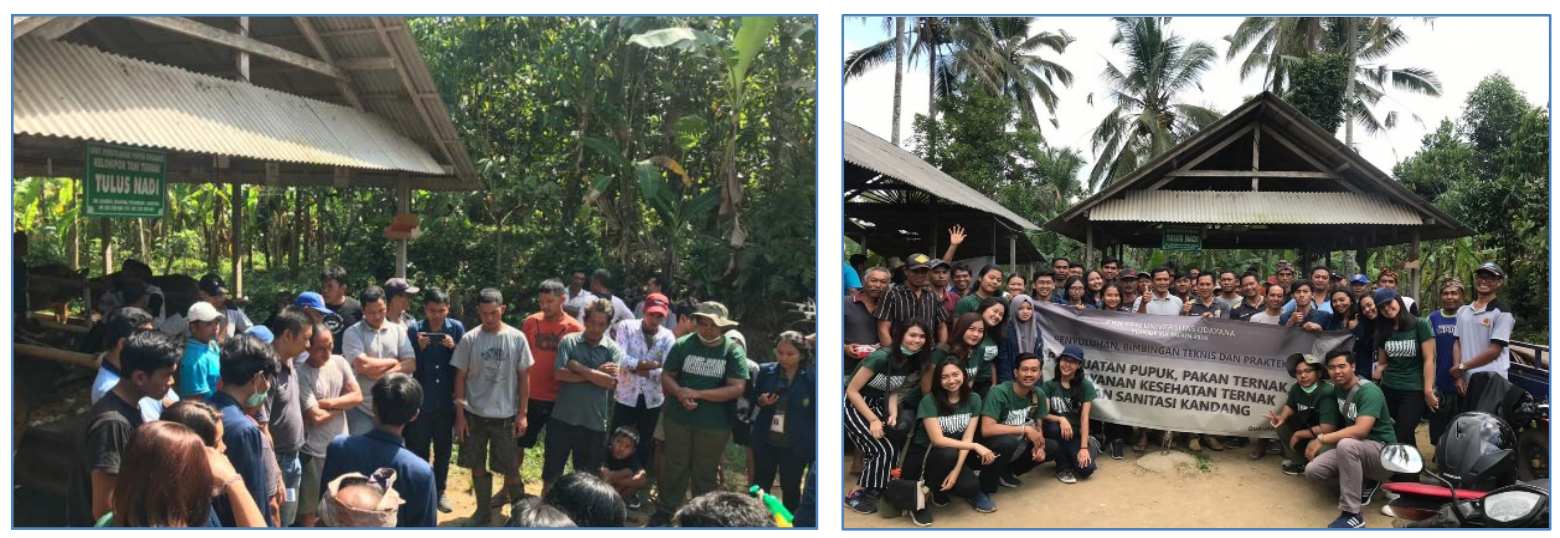

Gambar 3. Pembuatan pakan ternak dari jerami padi dengan biofermentasi biochast

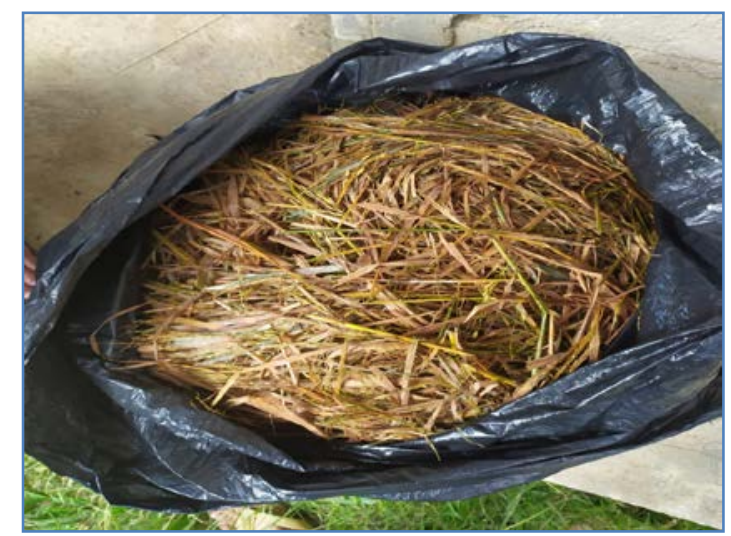

Gambar 4. Hasil pakan ternak dari jerami dengan teknologi biofermentasi biochast

Pelaksanaan kegiatan mulai dari penyuluhan teknologi biofermentasi biochast, demontrasi pembuatan pupuk dari jerami padi dan hasil pakan ternak yang sudah terfermentasi ditunjukkan pada Gambar 1 sampai Gambar 4.

\section{KESIMPULAN}

Kegiatan yang telah dilaksanakan sudah berjalan dengan baik dengan hasil yang dicapai yaitu anggota Kelompok Tani Tulus Nadi sudah mengetahui teknologi pembuatan pupuk dari limbah organik dengan memanfaatkan teknologi biofermentasi biochast. Selain mengetahui keuntungan penggunaan metode ini, mereka juga sudah mampu mempraktekkan dan membuat membuat pupuk dari jerami padi dengan menggunakan biofermentasi biochast. Diharapkan dengan kegiatan ini peternak memiliki alternatif pakan ternak dan yang terpenting adalah pakan ternak ini bisa disimpan dalam waktu 3-4 bulan.

\section{DAFTAR PUSTAKA}

1. Badan Pusat Statistik (BPS) Provinsi Bali. 2015. Bali dalam Angka 2015. Badan Pusat Statistik Provinsi Bali Tahun 2015. 
Penerapan Teknologi Biofermentasi untuk Pembuatan Pakan Ternak pada Kelompok Tani Ternak Tulus Nadi di Desa Buahan

2. Dinas Pertanian Tanaman Pangan Pemerintah Provinsi Bali. 2014. Sistem Pertanian Terintegrasi (Simantri) Provinsi Bali. Denpasar.

3. Ilham, N. 1995. Strategi Pengembangan Ternak Ruminansia di Indonesia. Forum Penelitian Agro Ekonomi. Pusat Penelitian Sosial Ekonomi Pertanian. Badan Penelitian dan Pengembangan Pertanian, Departemen Pertanian. FAE, 13 : 33-43.

4. Soebarinoto. 1997. Studi Potensi Hijauan pakan dalam Rangka Pengembangan Sapi Perah di Grati. Buletin Peternakan. 2 : 142. 